\title{
Seasonal abundance, vertical distribution and life history traits of Mediterranean mud shrimp Upogebia pusilla (Decapoda: Gebiidea) on the Slovenian coast
}

\author{
Jure JUGOVIC ${ }^{1}$, Eva HORVAT ${ }^{1}$ and Lovrenc LIPEJ ${ }^{1,2}$ \\ ${ }^{1}$ Department of Biodiversity, Faculty of Mathematics, Natural Sciences and Information \\ Technologies, University of Primorska, Glagoljaška 8, 6000 Koper, Slovenia \\ ${ }^{2}$ Marine Biology Station, National Institute of Biology, Fornače 41, 6330 Piran, Slovenia \\ *Corresponding author, e-mail: jure.jugovic@upr.si
}

\begin{abstract}
We studied seasonal abundance, vertical distribution and life history traits of the Mediterranean mud shrimp (Upogebia pusilla) in the mediolittoral zone in Slovenia. At two localities (Strunjan and Lazaret), quantitative samples from three plots $\left(1 \mathrm{~m}^{2}\right.$ each) at $(0 \mathrm{~cm})$, below $(-50 \mathrm{~cm})$ and above $(+50 \mathrm{~cm})$ mean water level were taken once every two months, in alternation. A set of parameters was also recorded, including vegetation cover, sediment type, air and sea temperature, $\mathrm{pH}$, salinity and oxygen levels. Highest abundance was recorded during the warm period of the year, with peak abundance in June 2012 (21\% of total sample). Lowest plots were always occupied with the highest densities of mud shrimps. Males dominated during the winter while ovigerous females reached the peak in June ( $>40 \%$ of all animals). In June at least $2 / 3$ of females were ovigerous. Estimated mean incubation period was 31 days. We determined four periods in relation to the species' reproductive activity. Early reproductive period (April) was characterised by emergence of first ovigerous females, while main reproductive period (May-July) was characterised by peak of reproduction. In post-reproductive (August-October), and non-reproductive (November-March) periods, no ovigerous females or newly hatched offspring were recorded.
\end{abstract}

Key words: abiotic factors, abundance, spatial variation, temporal variation

\section{INTRODUCTION}

Upogebia pusilla (Petagna, 1792) $[=U$. litoralis (Risso, 1816)] is one of the common decapod crustacean species of the family Upogebiidae (ATKINSON \& FROGLIA, 2000; ATKINSON \& TAYLOR, 2005; ROBLES et al., 2009; DE GRAVE et al., 2009; CONIDES et al., 2012), occurring in Mediterranean mediolittoral and subtidal soft sediments (DWORSCHAK, 1987a). As other thalassinidean species, $U$. pusilla used to be, and still is in some areas, harvested for use as bait for commercial and recreational fishing (INGLE, 1997; CONIDES et al., 2012; DWORSCHAK et al., 
2012). Distribution extends from eastern North Atlantic in the north to the coastline of Mauretania in the south; i.e. from Norway and the United Kingdom to the Red and Mediterranean Seas (NGOC-Ho, 2003). It can be found down to 45 $\mathrm{m}$ of depth, where a mixture of sand, silt, clay and mud (DWORSCHAK, 1987a) is present. Mud shrimp usually digs a burrow up to half a meter long and about one centimetre wide with two entrances. Its tunnels are "Y" shaped and water flow through is ensured (DWORSCHAK, 1983). Shrimps from this family are solitary and show aggressive intraspecific behaviour (RODRIGUES et al., 2000).

In mud shrimps, sexual dimorphism becomes evident when animals are maturing. Males are larger and heavier than females, and their propods of first pereopod's pair are relatively larger and heavier (DWORSCHAK, 1988). In males, however, hormonal disturbances induced by parasitism may sometimes result in female characteristics (cf. Pascal et al., 2016). Size of the animals is often dependent on the locality and its ecological parameters such as salinity, food limitation or incidence of parasitism (DWORSCHAK, 1988).

In the Mediterranean, studies on the ecology of $U$. pusilla were conducted in the Northern Adriatic Sea (Lido di Staranzano, near the mouth of the Isonzo river, Italy; in the Lagoon of Grado, Italy; and the mud flat in Val Saline near Rovinj, Croatia by DWORSCHAK (1987b) (see also DWORSCHAK, 1981; 1987a; 1988; 2004)), and in the Aegean (in the delta of Evros river; KEVREKIDIS et al., 1997) and Ionian (Dioni bay, Prefecture of Etoloakarnania; CONIDES et al., 2012) Seas in Greece. Not a single extensive study on species ecology exists for Slovenia. Our study was conducted at two localities: (1) a protected bay in Lazaret near Ankaran and (2) an artificial lagoon in Strunjan.

The purpose of this study was to investigate the seasonal abundance of $U$. pusilla in two coastal environments. Our goals were:

1) To document seasonal and vertical distribution and population structure of mud shrimps in the mediolittoral zone.

2) To describe the life history traits of the mud shrimp U. pusilla from a sheltered lagoon and a shallow bay on the Mediterranean coast in Slovenia.

3) To relate the time of the year and environmental conditions with the species abundance.

\section{MATERIAL AND METHODS}

\section{Sampling localities}

Mud shrimps were collected in the intertidal zone at two localities (Lazaret and Strunjan) on the Slovenian coast. In Lazaret, samples were collected in October and December 2011, and in February, April, June, and August 2012, while in Strunjan, samples were collected in November 2011, and in January, March, May, July and September 2012.

Lazaret ( $45^{\circ} 32^{\prime} 52^{\prime \prime} \mathrm{N}, 13^{\circ} 46^{\circ} 8^{\prime \prime} \mathrm{E}$; Fig. 1) is located close to the Slovenian-Italian border in San Bartolomeo Bay. The surrounding area includes agricultural lands (vineyards, olive groves and fields) with scattered settlements in between. Outflows of five small artificial channels flow in the bay, supposedly without significant hydro-morphological loads (ANONYMOUS, 2013). In this shallow area Cymodocea nodosa and most predominantely Zostera noltii (Hornemann, 1832) are present. Except for some Cyanobacteria biofilms, the upper mediolittoral horizon hosted almost no vegetation during the entire period of sampling. The highest part, however, is covered by halophytic vegetation of Spartina maritima (Curtis) Fernald and Juncus acutus L. (GLASNOVIĆ, 2006; MAČEK, 2013).

In Strunjan Landscape Park sampling was conducted in a transitional lagoon "Pretočna laguna" (in size of $1.6 \mathrm{ha}$, depth $0.5-1 \mathrm{~m}$ ) that connects an artificial Stjuža lagoon (11.2 ha) with the open sea (LIPEJ \& MAKOVEC, 1997) $\left(45^{\circ}\right.$ $31^{\prime} 30^{\prime \prime} \mathrm{N}, 13^{\circ} 36^{\prime} 20^{\prime}$ E; Fig. 1). An artificial barrier protects Pretočna laguna from the open sea. In the past, it was used for mariculture (e.g. Sparus aurata, Dicentrarchus labrax, Mugil sp. and Anguilla anguilla; ANONYMOUS, 2015). The water in Stjuža is shallow and its level is highly dependent on the tidal cycle (i.e. water 


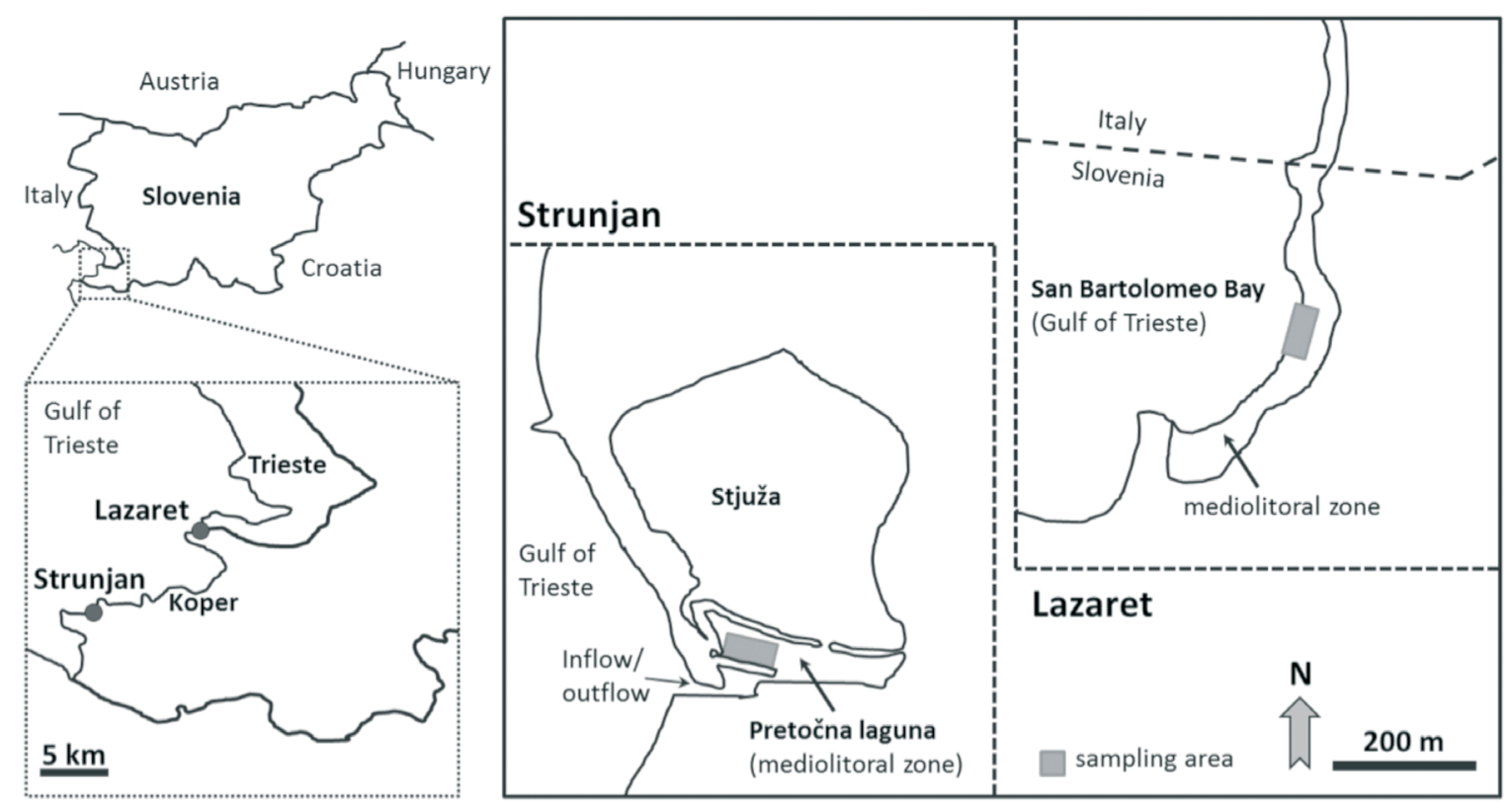

Fig. 1. Geographic position and details on two sampling localities of Upogebia pusilla, Lazaret (it. Lazaretto) and Strunjan (it. Strugnano) on Slovenian coast

flows through Pretočna laguna, see Fig. 1). Runoff waters from the neighbouring agricultural areas and local road as well as a small stream (Strunjanski potok) flows into Stjuža (LOTRIČ \& BREČKO GRUBAR, 2010). Marine phanerogams, $C$. nodosa and prevailing $Z$. noltii, cover the alluvial bottom of Stjuža (JOGAN et al., 2004; ŠAJNA \& KALIGARIČ, 2005).

\section{Fieldwork}

Three sampling plots $\left(1 \mathrm{~m}^{2}\right.$ each) were chosen at each sampling occasion, at (median plot), $50 \mathrm{~cm}$ below (lowest plot) and $50 \mathrm{~cm}$ above (highest plot) the mean sea level. We sampled on days with monthly lowest tides, following the hours of the low sea levels (LIČER et al., 2011; 2012).

We sampled the substrate from the three plots at each locality for the determination of the size fractions. While sampling of the animals was carried out on a bi-monthly basis between October 2011 and September 2012 (Table 1), sediment samples were collected once on April $6^{\text {th }}$ in Lazaret and on May $8^{\text {th }}$ in Strunjan.

During each sampling occasion we estimated vegetation cover (mainly of $Z$. noltii) for each of the plots (estimated by naked eye with an additional grid positioned on the sampling plot to $5 \%$ accuracy). Air (measured directly above the plot) and water temperatures $\left[{ }^{\circ} \mathrm{C}\right]$ were recorded with a thermometer $\left( \pm 0.5{ }^{\circ} \mathrm{C}\right.$ accuracy). We measured the temperature in the substrate of each plot at $10 \mathrm{~cm}$ depth in the same way. Mean air and water temperatures for each month were also collected from Slovenian Environmental Agency (LIČER et al., 2011; 2012).

At the edge of each of the three sampling plots, a sample of water was collected for measurements of $\mathrm{pH}$, salinity [\%o] and oxygen levels $[\mathrm{mg} / \mathrm{l}]$ that were conducted in a laboratory (Regional Institute of Public Health Koper) shortly afterwards. From the same three sampling plots, mud shrimps were collected, following DWORSCHAK (1988) and KEVREKIDIS et al. (1997). For the mud shrimps sampling we used $30 \mathrm{~cm}$ long pitchforks with wide tooth that were pushed into the firm sediment and moved back and forth. This created alternating water flow in the burrows ( $c f$. DWORSCHAK, 1988; KEVREKIDIS et al. (1997). Since animals could burrow deeper tunnels ( $c f$. DWORSCHAK, 1983), we also stirred the plot with our feet to cause fleeing of the animals to the surface. There is a possibility that some shrimps remained deep inside the burrows. Nevertheless, since the method was always 
the same we believe the numbers of collected shrimps can be used for comparison among different samples. Mud shrimps were fixed in $75 \%$ ethanol for measurements in the laboratory afterwards.

\section{Laboratory work}

Grain size distributions of the substrate were determined from dried sediment samples from three sampling plots of both localities. We used sieves with different mesh sizes (diameter of fractions: $<0.05 \mathrm{~mm}, 0.05-0.1 \mathrm{~mm}, 0.1-0.2 \mathrm{~mm}$, $0.2-0.5 \mathrm{~mm}, 0.5-1 \mathrm{~mm}, 1-2 \mathrm{~mm}, 2-75 \mathrm{~mm})$ and we weighted each fraction. Salinity [\%o], $\mathrm{pH}$ and oxygen levels [mg/l] for each of the water samples were measured with the electrodes of the instrument Muti 3420 (Wissenschaftlich-Technische-Werkstäten).

For each animal sex (male/female) was determined by assessing the presence (female) or absence (male) of the first pair of pleopods, and the potential presence of embryos was determined on pleopods of females (hereafter referred to as ovigerous females). In rare cases when parasites or their signs were present, and this may affect the appearance of pleopods, the shape of first propodus prevailed in sex determination (males have relatively wider propoda; see DWORSCHAK, 1988: Figs. 1 and 2). We counted animals and measured their wet body mass (BM) (scale Kern Als, \pm 0.1 g accuracy). With calliper ( $\pm 0.1 \mathrm{~mm}$ accuracy), we measured carapace length (CL, from the eyes to the back edge of the carapace) and total body length (TL, from the eyes to the end of the telson) of each individual. Each animal was vouchered with a unique tag and samples were stored in $75 \%$ ethanol.

\section{Statistical analysis}

First, we calculated proportions of the substrate fractions and compared the composition of substrate between sampling plots within and between the two sampling localities. We also compared vegetation cover between the plots, localities and time of the year.
In total, 1180 animals were sampled, of which 1149 (97.4\%: 658 from Lazaret and 491 from Strunjan) were included in the analysis of abundance. Monthly abundance of each gender category of mud shrimps (males, ovigerous and non-ovigerous females) were plotted to inspect the seasonal patterns of their occurrence at the locality and plot levels. In order to explain the influence of environmental parameters on the abundance of each gender category of mud shrimps in the mediolittoral zone, non-metric multidimensional scaling (NMDS, Euclidean distance) was used. Average values of sediment temperature, salinity [\%o] and vegetation cover [\%] from three plots for each sampling occasion were calculated before the analysis. From eight available environmental parameters (mean monthly sea temperature, sediment temperature measured in the field, mean monthly air temperature, air temperature measured in the field $\left[{ }^{\circ} \mathrm{C}\right], \mathrm{pH}$, oxygen levels [mg/l], salinity [\%o], vegetation cover [\%]) a subset of parameters was included in the final NMDS analysis. The selected parameters were sediment temperature and salinity measured on the field while the other six parameters were excluded due to high level of constancy $(\mathrm{pH})$, random effects (oxygen levels) and/or high correlations among the others (Spearman correlation coefficient). As some data were lacking for the first two months (October-November 2011), NMDS was conducted on samples from December 2011 on with the two selected parameters, and again with three available environmental parameters (mean monthly sea temperature, mean monthly air temperature, air temperature measured on the field) for all months. Minimum spanning tree was also plotted to inspect the connections between the closest pairs of samples in a multidimensional space. To inspect the correlation among pairs of environmental parameters and abundance of each gender category, Spearman correlation coefficients $(\rho)$ were calculated.

Morphological traits (BM, TL, CL) were summarised by descriptive statistics for each gender category and locality (Lazaret, Strunjan). Average values were tested for possible statistical differences between the two localities with 
One-way T-test $(\mathrm{p}<0.05)$. We calculated the Pearson correlation coefficient (r) for the three morphological traits.

Fecundity ratio was determined as the ratio between the number of ovigerous females and the number of non-ovigerous mature females. As we did not study the development of gonads to determine maturity with certainty (DWORSCHAK, 1988), only females with total body length equal to or longer than in smallest ovigerous female from our samples were considered adults (see DWORSCHAK, 1988). In addition, we calculated the proportion of ovigerous females (i.e. of all adult females) in the total population. Approximation of incubation time was calculated from formula proposed by HILL (1977): $\log \mathrm{I}=-1.881$ $* \log \mathrm{T}+3.826(\mathrm{I}=$ number of days; $\mathrm{T}=$ mean water temperature in ${ }^{\circ} \mathrm{C}$; see also DWORSCHAK, 1988).

Statistical analyses were performed in MS Excel 2010, SPSS Statistical package (ver. 20; SPSS Inc. 1989-2011) and freely available software PAST (PAlaeontological STatistics, ver. 2.16: folk.uio.no/ohammer/past/; see HAMMER, 1999 - 2013).

\section{RESULTS}

\section{Environmental parameters}

In Lazaret more than one third of substrate $(\sim 37 \%)$ was composed of large gravel (fractions larger than $2 \mathrm{~mm}$ in diameter), and additional

(a)

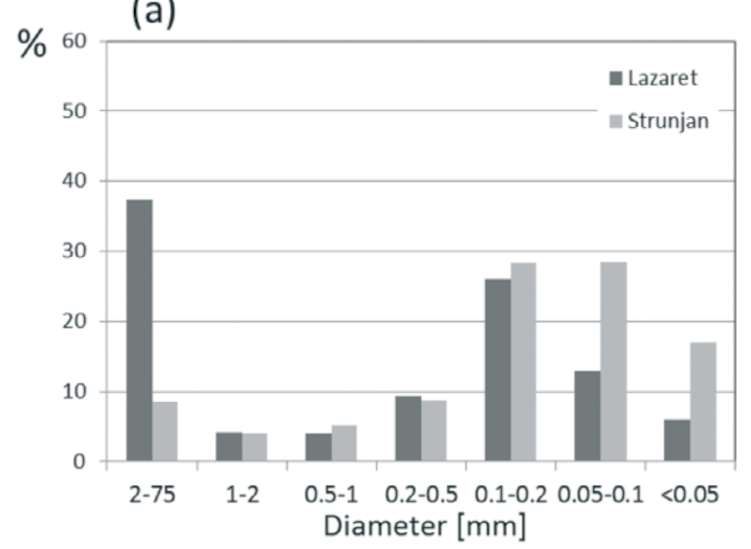

quarter $(\sim 26 \%)$ was composed of fine sands (diameter: $0.1-0.2 \mathrm{~mm}$ ), followed by fractions of silt $(0.05-0.1 \mathrm{~mm})$. In Strunjan, smaller fractions of fine sands $(0.1-0.2 \mathrm{~mm})$ and fractions of silt $(0.05-0.1 \mathrm{~mm})$ with $\sim 27 \%$ each were prevailing, followed by a smaller fraction of silt $(<0.05 \mathrm{~mm} ; \sim 17 \%)$. Other fractions are represented in smaller percentages (Fig. 2a). In Strunjan, proportion of the silt fraction was increasing towards lower mediolittoral zone, whereas in Lazaret higher substrate heterogeneity was recorded (Fig. 2b).

Vegetation cover, consisted of Zostera noltii, changed through sucessive sampling periods and differed between the two sampling localities (Table 1). Most of the time, the high sampling plots were poorly covered $(<20 \%)$. In general, less vegetation was present in Strunjan than in Lazaret during spring and summer (Table 1).

We recorded the lowest air temperature in March 2012 in Strunjan $\left(1^{\circ} \mathrm{C}\right.$; mean March temperature: $9.9{ }^{\circ} \mathrm{C}$; Table 1). From spring onwards the temperature was rising through the successive sampling occasions. On July $4^{\text {th }} 2012$ at 6 am we measured the highest temperature: $24.9{ }^{\circ} \mathrm{C}$ (mean July temperature: $25.5^{\circ} \mathrm{C}$ ). No differences were recorded among the sampling plots within one sampling period. Similar seasonal pattern was observed in mean monthly sea temperatures (Fig. 3) and sediment temperatures measured in the field (Table 1). For the latter, only small differences were detected between the plots (Table 1).

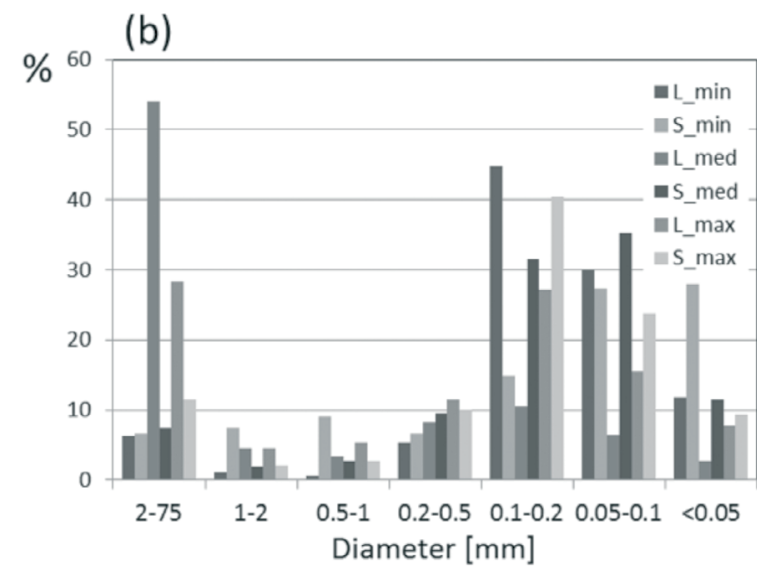

Fig. 2. Proportions of sediment fractions based on particle diameter at (a) locality level and (b) plot level (L-Lazaret, $S$-Strunjan; min, med, max - sampling plots below, at and above mean sea level, respectively) 
Table 1. Summary data on environmental parameters from Lazaret and Strunjan in period from October 2011-September 2012. Extreme values in bold; n.d. - no data. Values from min, med and max plots, respectively, are separated by slashes (/)

\begin{tabular}{|c|c|c|c|c|c|c|c|c|}
\hline Sampling date (locality) & $\begin{array}{c}\text { Tsea } \\
\text { mean } \\
{\left[{ }^{\circ} \mathrm{C}\right]}\end{array}$ & $\begin{array}{c}\text { Tsed } \\
{\left[{ }^{\circ} \mathrm{C}\right]}\end{array}$ & $\begin{array}{l}\text { Tair_ } \\
\text { mean } \\
{\left[{ }^{\circ} \mathrm{C}\right]}\end{array}$ & $\begin{array}{r}\text { Tair } \\
{\left[{ }^{\circ} \mathrm{C}\right]}\end{array}$ & $\mathrm{pH}$ & $\begin{array}{r}\mathrm{O}_{2} \\
{[\mathrm{mg} / \mathrm{l}]}\end{array}$ & $\begin{array}{r}\text { Sal } \\
{[\%]}\end{array}$ & $\begin{array}{l}\text { Veg } \\
\text { [\%] }\end{array}$ \\
\hline Oct $25^{\text {th }} 2011$ (Lazaret) & 19.4 & n.d. & 12.6 & 17.0 & n.d. & n.d. & n.d. & n.d. \\
\hline Nov $26^{\text {th }} 2011$ (Strunjan) & 15.8 & n.d. & 8.6 & 16.0 & n.d. & n.d. & n.d. & $70 / 40 / 5$ \\
\hline Dec 23 ${ }^{\text {rd }} 2011$ (Lazaret) & 13.3 & $9.5 / 9.0 / 9.0$ & 7.3 & 9.0 & 7.88/7.21/7.85 & $6.36 / 8.61 / 5.69$ & n.d./ n.d. $/ 36.2$ & $80 / 25 / 25$ \\
\hline Jan $21^{\text {st }} 2012$ (Strunjan) & 10.8 & $10.0 / 8.0 / 9.0$ & 3.5 & 10.0 & 7.92/6.85/7.20 & $1.86 / 7.0 / 6.01$ & $37.8 / 38.1 / 38.0$ & $5 / 5 / 0$ \\
\hline Feb $19^{\text {th }} 2012$ (Lazaret) & 7.4 & $8.0 / 8.5 / 6.0$ & 1.5 & 8.0 & $\mathbf{8 . 5 4} / 8.06 / 7.80$ & $\mathbf{1 1 . 1 8} / 9.45 / 7.52$ & $38.0 / 37.4 / 38.0$ & $80 / 5 / 20$ \\
\hline Mar $6^{\text {th }} 2012$ (Strunjan) & 9.3 & $7.5 / 8.5 / 6.5$ & 9.9 & 1.0 & $8.17 / 7.8 / 8.03$ & $8.54 / 5.91 / 8.77$ & 38.5/39.2/39.2 & $20 / 5 / 0$ \\
\hline Apr $6^{\text {th }} 2012$ (Lazaret) & 12.6 & $13.0 / 12.5 / 12.5$ & 12.8 & 13.0 & 7.61/7.82/7.71 & $3.72 / 5.20 / 2.66$ & $37.7 / 22.2 / 30.7$ & $60 / 20 / 5$ \\
\hline May $8^{\text {th }} 2012$ (Strunjan) & 17.0 & $15.5 / 15.0 / 15.0$ & 16.6 & 13.0 & 7.11/7.08/7.14 & $0.78 / 1.26 / 0.86$ & $36.0 / 36.2 / 33.8$ & $25 / 55 / 0$ \\
\hline Jun $4^{\text {th }} 2012$ (Lazaret) & 23.1 & $18.0 / 17.5 / 17.0$ & 22.7 & 17.0 & 7.59/7.56/7.62 & $3.5 / 0.70 / 3.08$ & $34.3 / 34.6 / 32.9$ & $100 / 60 / 5$ \\
\hline Jul $4^{\text {th }} 2012$ (Strunjan) & 26.1 & 25.5/24.0/22.5 & 25.5 & 25.0 & 7.45/7.44/7.50 & $0.60 / 0.42 / 0.32$ & $35.6 / 35.8 / 35.7$ & $100 / 60 / 5$ \\
\hline Aug $21^{\text {st }} 2012$ (Lazaret) & 26.0 & $21.5 / 21.5 / 21.5$ & 24.7 & 23.0 & 7.61/7.82/7.46 & $0.10 / 0.10 / 0.15$ & $37.8 / 37.7 / 38.4$ & $100 / 80 / 20$ \\
\hline Sep 16 2012 (Strunjan) & 23.0 & $22.5 / 23.0 / 23.5$ & 19.8 & 24.0 & $7.25 / 7.46 / 7.67$ & $0.45 / 0.25 / 0.95$ & $38.1 / 38.8 / 39.2$ & $100 / 100 / 70$ \\
\hline
\end{tabular}

Acronyms: Tsea_mean: mean monthly sea temperature $\left[{ }^{\circ} \mathrm{C}\right]$, Tsed : sediment temperature $\left[{ }^{\circ} \mathrm{C}\right]$, Tair_mean : mean monthly air temperature $\left[{ }^{\circ} \mathrm{C}\right]$, Tair: air temperature $\left[{ }^{\circ} \mathrm{C}\right]$, O2: oxygen [mg/l], Sal: salinity [\%o], Veg: vegetation cover [\%].

Most of $\mathrm{pH}$ measurements were between 7 and 8 , with the only exception above 8 in late winter (February, March) at lowest plots (min, med) in both localities. During the winter months (December 2011 in Lazaret and January 2012 in Strunjan), highest differences among the three plots were recorded, with lower values of pH at higher plots. In spring (May 2012) values were generally the lowest (only slightly above 7, Table 1).

Oxygen values $[\mathrm{mg} / \mathrm{l}]$ were highest during winter months, with peak in February (Lazaret) and March (Strunjan) 2012 (Table 1: $11.18 \mathrm{mg} / 1$ in February and $8.54 \mathrm{mg} / \mathrm{l}$ in March). During late spring, summer and autumn months (May-September 2012) we recorded hypoxic $(<2 \mathrm{mg} / \mathrm{l})$ and almost anoxic conditions at some plots (Table 1).

\section{Seasonal and vertical abundance and density}

We caught most animals in median and lowest plots in Lazaret. Numbers of animals were decreasing towards the highest plots in both locations. Highest abundance was recorded from late spring to early summer (June-July 2012), whereas lowest abundance was recorded from late autumn until early spring (November 2011March 2012; Fig. 3). In October 2011 and in period from April-September 2012, we caught more than 100 animals per sampling occasion in both locations, while less than 50 were caught during each of all other occasions.

We recorded ovigerous females from April to July in both sites, with peak in June (Fig. 3). Females represented more than $60 \%$ of the Lazaret's samples in June (Fig. 3). Males were most prevalent in March 2012 (i.e. slightly above $60 \%$ ), one month before ovigerous females appeared (Fig. 3). In Lazaret, ovigerous females were most abundant in median and lowest plots and were not yet recorded at highest plot in April 2013. Regardless of gender, animals were particularly scarce in highest plots during the coldest part of a year (November 2011March 2012). During all sampling occasions, we recorded some animals at least in lowest plots. Higher plots in Lazaret (mean values for males $(\min :$ med $: \max )=54 \%: 38 \%: 8 \%$; females $=53 \%: 44 \%: 3 \%$; ovigerous females $=52 \%$ : $38 \%: 10 \%$ ) were always less occupied than in Strunjan $($ males $=38 \%: 32 \%: 30 \%$; females $=$ 


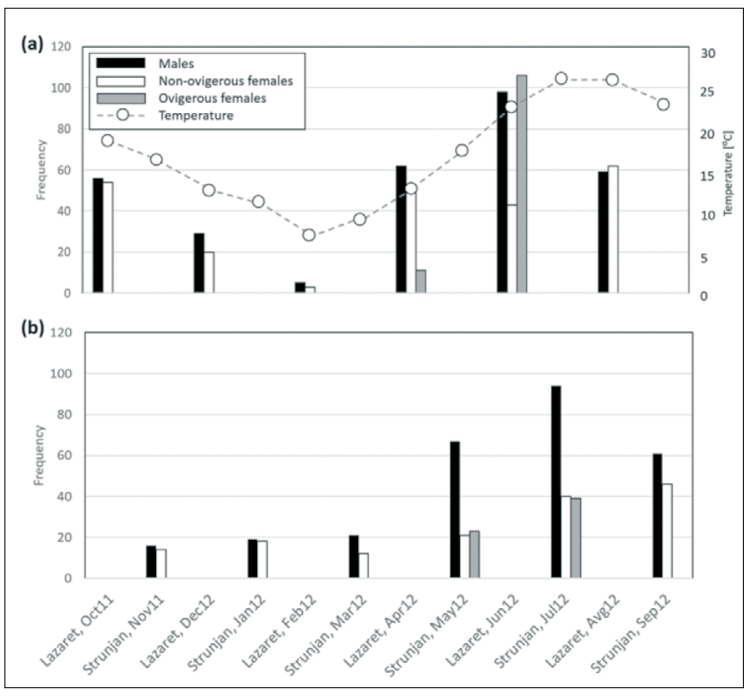

Fig. 3. Abundance (frequency) of mud shrimps at Lazaret (a) and Strunjan (b) in period from October 2011-September 2012 (mean monthly sea temperatures added)

$52 \%: 26 \%: 22 \%$; ovigerous females $=44 \%:$ $34 \%: 22 \%)$.

Abundance of each gender category from both sampling sites corresponds to environmental parameters well, as shown by non-metric multidimensional scaling analysis (Fig. 4). Ten samples from December 2011-September 2012 clustered into four groups that we classified by reproductive activity (Fig. 4). Salinity almost exclusively characterises the first axis (higher salinity on the left), and sediment temperature was changing mostly along the second axis (Table 2). During 'main reproductive period', water and air temperatures were high, while $\mathrm{pH}$, salinity and levels of oxygen were low (Table 1). In 'early reproductive' and 'post-reproductive' periods, in April and August-September, respectively, environmental parameters were mainly similar. During 'non-reproductive' season, temperatures were lowest, but vice versa $\mathrm{pH}$, salinity and levels of oxygen were highest (Table 1).

Table 2. Scores for environmental parameters in nonmetric multidimensional scaling of mud shrimps' abundance on Slovenian coast

\begin{tabular}{llrr}
\hline Parameter & (Abbreviation) & Axis & Axis \\
& & 1 & 2 \\
$\begin{array}{l}\text { Sediment } \\
\text { temperature }\end{array}$ & (Tsed) & 0.59 & 0.41 \\
Salinity & $($ Sal) & -0.49 & 0.01 \\
\hline
\end{tabular}

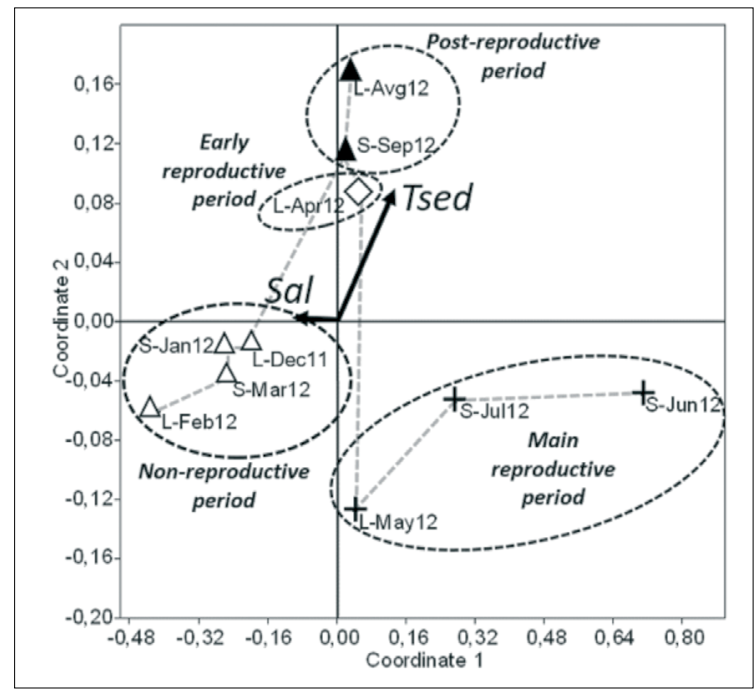

Fig. 4. Non-metric multidimensional scaling of dependence of mud shrimps' abundance (abundance of males, abundance of non-ovigerous females, abundance of ovigerous females) upon two environmental parameters (shown as vectors: Tsed - sediment temperature Sal - salinity; see Table 1) from December 2011-September 2012. Minimum spanning tree is represented by gray broken lines. Four periods were identified (depicted in black elipsoids with broken lines). For each score, average values from three sampling plots were used. S - Strunjan, L - Lazaret

Lowest vegetation cover also characterised this period. In repetition of analysis with all twelve samples but only with three environmental variables (mean monthly sea temperature, mean monthly air temperature, air temperature measured in the field; see Table 1), clusters remained the same: sample from October 2011 clustered with samples from post-reproductive period, and sample from November 2011 clustered together with samples from non-reproductive period. Spearman correlations among pairs of variables and of those with abundance of animals are in Appendix A.

\section{Size, weight, fecundity and incubation period}

On average, size (TL, CL) and weight (BM) of males, non-ovigerous females and ovigerous females was smaller in Lazaret than in Strunjan (Table 3). Except for ovigerous females (one way T-test, $p=0.095$ ) the differences were statistically significant $(p<0.001)$ between the two 
Table 3. Mean wet body mass (BM), total body length (TL) and carapace length (CL) with standard deviations (in brackets) for males, non-ovigerous and ovigerous females from Lazaret and Strunjan

\begin{tabular}{|c|c|c|c|c|c|c|}
\hline & \multicolumn{2}{|l|}{ Males } & \multicolumn{2}{|l|}{ Females } & \multicolumn{2}{|c|}{ Ovigerous females } \\
\hline & Lazaret & Strunjan & Lazaret & Strunjan & Lazaret & Strunjan \\
\hline $\mathrm{BM}[\mathrm{g}]$ & $0.68(0.58)$ & $1.14(0.75)$ & $0.60(0.38)$ & $0.88(0.45)$ & $1.16(0.58)$ & $1.27(0.47)$ \\
\hline $\mathrm{TL}[\mathrm{mm}]$ & $27.9(8.1)$ & $34.7(9.3)$ & $27.7(7.4)$ & $33.8(6.8)$ & $36.3(6.0)$ & $39.1(5.0)$ \\
\hline $\mathrm{CL}[\mathrm{mm}]$ & $9.5(2.8)$ & $12.0(3.6)$ & $9.3(2.7)$ & $11.6(1.9)$ & $11.8(1.9)$ & $12.6(1.7)$ \\
\hline
\end{tabular}

localities. In addition, the mean total (TL) and carapace lengths $(\mathrm{CL})$ were smaller in Lazaret (one way T-test, $\mathrm{p}<0.003$ ). The smallest ovigerous female measured $26.4 \mathrm{~mm}$ in TL. Pearson correlations between TL, CL and BM were high $(\mathrm{r}>0.6$ in each gender category: males (range 0.82-0.90), non-ovigerous (range 0.61-0.83) and ovigerous females (range $0.80-0.90)$ ) and statistically significant $(\mathrm{p}<0.001)$.

Most common $2 \mathrm{~mm}$ size classes of total length in males and non-ovigerous females were from 30 to $32 \mathrm{~mm}$ in Lazaret, while in Strunjan the most common size class in males was from 40 to $42 \mathrm{~mm}$, and from 36 to $38 \mathrm{~mm}$ in nonovigerous females. In ovigerous females, size classes from 32 to $34 \mathrm{~mm}$ and 38 to $40 \mathrm{~mm}$ were most common in Lazaret and Strunjan, respectively (Fig. 5). Frequency distributions of $5 \mathrm{~mm}$ size classes for each sampling occassion are shown in Appendix B.

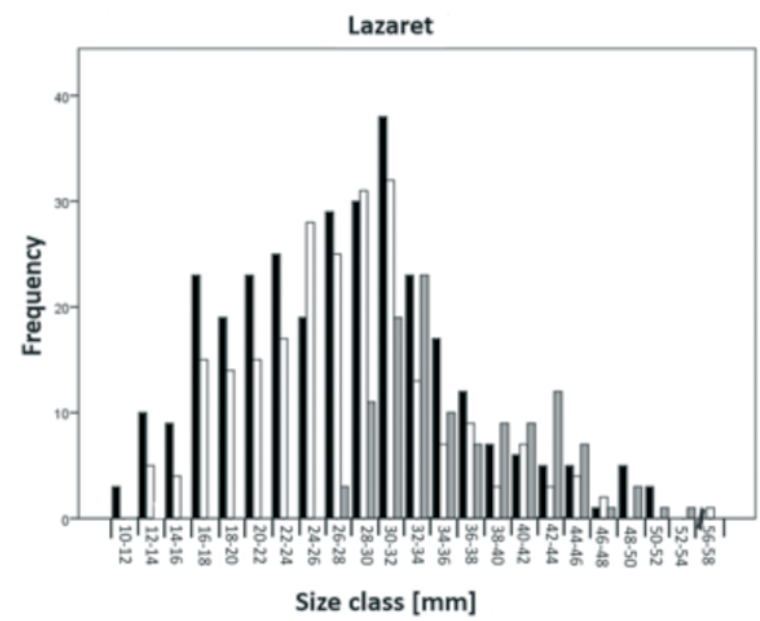

Fecundity ratio increased from early reproductive period in April until its peak in June, and decreased by July (Table 4). At first, no ovigerous females were present at highest plots, however the fecundity ratio slowly increased at all plots as the reproductive season proceeded. In addition, the proportion of ovigerous females slowly increased from April to June. In June 65 $\%$ of adult females were ovigerous (Table 4); the proportion of ovigerous females decreased afterwards. Except for the first and last month of the reproduction (April, July), vast majority of adult females are ovigerous in between (May, June). In July, approximately every second adult female were ovigerous (Table 4). We calculated that first offspring hatched at the end of May and the last one in second half of July (Table 5). Mean incubation time in mud shrimps from Slovenia lasted for 31 days.

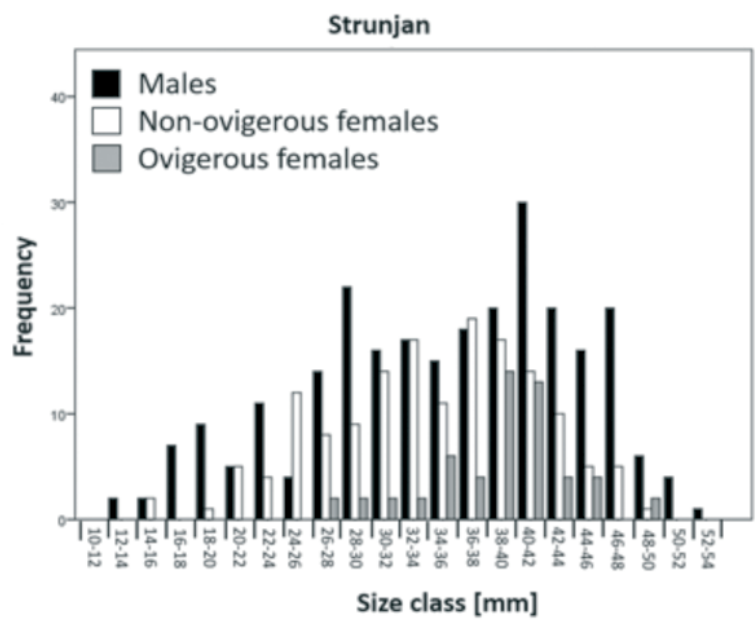

Fig. 5. Two millimeters size classes of total body length (TL) in males, non-ovigerous and ovigerous females of Upogebia pusilla from Lazaret (left) and Strunjan (right) at Slovenian coast 
Table 4. Fecundity ratio (FR $=$ ovigerous females/nonovigerous mature females) and proportion of ovigerous females (Fov = ovigerous females/adult females) in three sampling plots during from April-July 2012 in Lazaret (April, June) and Strunjan (May, July)

\begin{tabular}{lccccccccc}
\hline & \multicolumn{1}{c}{$\begin{array}{l}\text { Sampling } \\
\text { plot }\end{array}$} & \multicolumn{2}{c}{ April } & \multicolumn{2}{c}{ May } & \multicolumn{2}{c}{ June } & \multicolumn{2}{c}{ July } \\
\cline { 2 - 9 } min & Fov & FR & Fov & FR & Fov & FR & Fov \\
\hline med & 0.42 & 0.29 & 3.00 & 0.75 & 3.92 & 0.80 & 1.33 & 0.57 \\
$\max$ & 0.08 & 0.07 & 2.00 & 0.67 & 3.92 & 0.80 & 0.47 & 0.32 \\
Mean & 0.00 & 0.00 & 0.50 & 0.33 & 0.57 & 0.36 & 1.83 & 0.65 \\
\cline { 2 - 9 } & 0.17 & 0.12 & 1.83 & 0.58 & 2.80 & 0.65 & 1.21 & 0.51 \\
\hline
\end{tabular}

Table 5. Aproximate dates of hatchings according to mean monthly temperature $\left[{ }^{\circ} \mathrm{C}\right]$, calculated as proposed by HILL, 1977: $\log I=-1.881 * \log T+3.826(I=$ incubation time in days; $T=$ mean monthly water temperature in ${ }^{\circ} \mathrm{C}$ ). Fresh ova are assumed on a sampling day

\begin{tabular}{|l|l|l|l|}
\hline $\begin{array}{l}\text { Sampling } \\
\text { date } \\
\text { (locality) }\end{array}$ & $\begin{array}{l}\text { Mean } \\
\text { monthly } \\
\text { temperature }\end{array}$ & $\begin{array}{l}\text { Incubation } \\
\text { time [days] }\end{array}$ & $\begin{array}{l}\text { Day of } \\
\text { hatching }\end{array}$ \\
\hline $\begin{array}{l}\text { April 6 } \\
\text { (Lazaret) }\end{array}$ & 12.8 & 55 & 31.5 .2012 \\
\hline $\begin{array}{l}\text { May } 8^{\text {th }} 2012 \\
\text { (Strunjan) }\end{array}$ & 16.6 & 34 & 11.6 .2012 \\
\hline $\begin{array}{l}\text { June } 4^{\text {th }} 2012 \\
\text { (Lazaret) }\end{array}$ & 22.7 & 19 & 23.6 .2012 \\
\hline $\begin{array}{l}\text { July 4 } \\
\text { (Strunjan) } 2012\end{array}$ & 25.5 & 15 & 19.7 .2012 \\
\hline
\end{tabular}

\section{DISCUSSION}

The present study is the first to study the occurrence of mud shrimps below and above the mean sea level, i.e. at the highest limit of their occurrence. There is a well expressed seasonal dynamics in abundance in the mediolittoral zone, with some differences in altitudinal abundance, as well as differences between the two study localities. Due to difficulties of sampling we had to sample during low tide levels in order to reach the lowest plots. Since the time of the tides varied substantially among the sampling occasions (cf. LIČER et al., 2011; 2012), we focused on seasonal rather than diurnal dynamics.

Seasonal pattern in abundance, densities, sexual ratio and reproductive period was evident between the two localities and among plots. Abundance varied more by season than between localities. The seasonal patterns were clear despite (1) the recorded differences in substrate and vegetation cover, (2) the distance $(12 \mathrm{~km})$ and (3) bimonthly samplings in alternations between both localities. Hence, the time pattern in abundance corresponded well to seasonality and time changes in abiotic and biotic conditions reported in previous studies (DWORSCHAK, 1988; CONIDES et al., 2012).

Although mud shrimps inhabit different sediment types, they appear to prefer sediment of smaller particles (DWORSCHAK, 1987a; KEVREKIDIS et al., 1997). Nevertheless, as in other studies, we cannot derive direct correlation between the mud-shrimp density and sediment size; we only noticed higher densities at lower plots where smaller particles (fine sands and silt) prevailed. Higher densities at these plots can also be related to the pattern of vertical distribution; in lowest plots, the water persists for most of the time so the food there is more abundant [for Upogebia pugettensis (Dana, 1852), see MACGINITIE \& MACGINITIE, 1968].

All environmental parameters included in our statistical analysis correlate well with seasonal abundance of mud shrimps. Reproductive period that lasts from early April until late July thus coincides with lower values of $\mathrm{pH}$, oxygen and salinity, higher temperatures and well expressed vegetation cover (especially of Zostera noltii). The duration of reproductive period is highly dependent on the temperature cycle of the biotope; for the Mediterranean region, DWORSCHAK (1988) reports presence of ovigerous females from March to July. Higher oscillations in abiotic parameters in the Northern Adriatic Sea are predicted to be the main reason for shorter reproductive period than in the Central or Southern Adriatic (FERRARESE et al., 2009). Furthermore, mud shrimps are sensitive to longer periods of hypoxia that together with eutrophication caused the dramatic decrease of population on the coast of the Black sea in Bulgaria (TODOROVA \& KONSULOVA, 2000). Moreover, $\mathrm{pH}$ values and oxygen levels inside the tunnels were found to be very different from those in the open waters or in sediment close to the bottom (DWORSCHAK, 1987a). Although 
the salinity during the reproductive season was lower than reported for the open sea ( $\sim 38-39 \%$, e.g. GRBEC et al., 2007, see Table 1) it was almost as high as in water analysis from Rovinj in NW Croatia (DWORSCHAK, 1988). It was also higher than the optimal value reported for the adults $(\sim 26 \%)$ but close to the optimum reported for larval development $(\sim 35 \%$; see DWORSCHAK, 1988).

Similar as in the study from northern Greece (KEVREKIDIS et al., 1997), animal density was highest in the warmest and lowest in the coldest part of the year. Density increased in the period from spring until summer and decreased from late summer onwards. The density coincides best with mean monthly sea and sediment temperatures (Fig. 3 and 4); high positive correlations were detected among them. Small numbers of collected animals during 'non-reproductive' period can be explained by: 1) animals burrow themselves deeper in the sediment during the cold period, 2) migrations between areas may influence the lower number of animals sampled during the winter or 3 ) the mortality rate during winter is high. Due to difficulties in sampling it is almost impossible to establish which of the scenarios is the most likely the one. In Greece, CONIDES et al. (2012) estimated 0.93 rate of overall natural mortality per year. Nevertheless, also in the latter case the actual reason for high estimate of natural mortality could have stayed hidden.

Temperature and salinity are most often reported as key factors influencing population structure and activity patterns. Both factors also cause the disturbance for different species in brackish environments (KAISER et al., 2011). Towards the northern geographic latitudes mean temperature is decreasing which can represent a stress factor for animals - also mean size in $U$. pusilla coincides well with geographic latitude. Both mentioned factors along with the issues related to the sampling procedures led to a different population structure at different localities (cf. LAPRISE \& Dodson 1994). We also have to consider a different pressure by fishermen on adult $U$. pusilla at both localities (Lazaret and Strunjan). In the Mediterranean, the animals (expressed as total body length) are largest in Greece (KEVREKIDIS et al., 1997) and smallest in the Northern Adriatic (DWORSCHAK, 1988). Mean size of mud shrimps from Slovenian coast exceed only the size of animals from Rovinj, located only ca. $50 \mathrm{~km}$ to the south. High oscillation and decrease in salinity during reproductive period seem to affect the animal growth negatively and may delay the development and metamorphosis in larvae (COSTLOW \& BOOKHOUT, 1971). CONIDES et al. (2012) reported the reduced ability of food intake and its digestion in such conditions. In Rovinj (DWORSCHAK, 1988), mud shrimps are most probably smaller due to sheltered bay and less inflow of nutrient rich water from the open waters. The difference in shrimp size between the two Slovenian localities could be explained by habitat characteristics. Smaller size in lagoon environment (Strunjan) should be expected due to high oscillations of environmental factors such as temperature, salinity and also oxygen availability (cf. CONIDES et al., 2012). However, mud shrimps from Lazaret proved to be smaller. We believe this is the result of harvesting of the mud shrimps by fishermen as according to our observation, mud shrimps were much more exploited in Lazaret than in Strunjan (JUGOVIC \& HORVAT, unpubl.). Fishermen generally try to collect larger animals that are more useful as bait and are also much easier to detect (cf. CONIDES et al., 2012).

Vertical distribution of mud shrimps shows differences particularly in the abundance of ovigerous females between the two localities. Their density was similar across the three plots in Strunjan, and ovigerous females were constantly present at highest plots. In Lazaret, however, density was much lower at highest plots. The difference in duration in tides and their amplitude between Strunjan and Lazaret may have important influence on the animal densities. In Lazaret areas are exposed for longer periods which may have an effect on the shrimps on higher plots, while the lagoon in Strunjan minimizes the tidal differences. Moreover, the size differences in animals between both localities imply that larger animals in Strunjan may be able to build deeper burrows and are therefore more prone to survive 
the exposure to low tides, and are also harder to collect by fishermen. Although we have seen fishermen collecting mud shrimps in both localities, we believe that in Strunjan is harder to efficiently collect animals than at the locality near Lazaret. Additionally, less fishermen collect mud shrimps in Strunjan as this is a Natura 2000 site (see above).

Despite the sampling difficulties, we do not believe the abundance of animals estimated from collected animals was much affected by the sampling technique. The abundance of animals however was also calculated from additional counting of the burrow openings from the same sampling plots (HORVAT, 2013) and these latter estimates roughly matches to estimates of abundance derived from sampling method used in present study. As lower oscillations in environmental parameters are predicted for deeper waters, it is no surprise that densities of ovigerous females and their fecundity rates are higher at lowest plots, especially when these are distant from shallower areas.

\section{CONCLUSIONS}

We documented seasonal and vertical distribution and population structure of mud shrimps in the mediolittoral zone of the Slovenian coast, showing highest abundance in the warm part of the year (maximum in June), when ovigerous females and most of the offspring were present (April-July). Highest densities were detected at the lowest plots, which are with the exception at the time of lowest monthly tides constantly underwater. Mean duration of the incubation period was estimated to be 31 days. Finally, seasonality well reflected the changes in abiotic factors among the seasons.

\section{ACKNOWLEDGEMENTS}

We would like to acknowledge Tjaša ZAGORŠEK, Martin GRANDO, Mitja ČRNE, Eva PRAPROTNIK, Kaja VUKOTIĆ, Neža GREGORIČ and Liljana RUŠNJAK for assistance in the field. Liljana RUŠNJAK and Alenka KOŽELJ kindly helped with laboratory analyses of chemical parameters at Regional Institute of Public Health Koper. Special thanks go to David KURUČEV and Peter MARIČIĆ who showed us the site near Lazaret and provided us with first information on pitchfork techniques of collecting the shrimps. Zorko VIČAR (Slovenian Environmental Agency) is acknowledged for providing data on mean monthly temperatures of the Slovenian sea during sampling period. Bojan LAZAR and Andrej SOVINC are acknowledged for useful discussions and hints while preparing the manuscript. Živa FIŠER PEČNIKAR and Tilen GENOV kindly reviewed the manuscript and English. We would like to thank the reviewers for their constructive comments. We also thank Robert TURK and Alenka POPIČ for preparation of sampling permission (No. 7-II-151/2-O-11/AP) for Strunjan Landscape Park.

\section{REFERENCES}

ANONYMOUS. 2013. Izvajanje vodne direktive na Vodnem območju Jadranskega morja. Ljubljana: Ministry of the Environment and Spatial Planning (http://www.arhiv.mop. gov.si/fileadmin/mop.gov.si/pageuploads/ podrocja/okolje/pdf/vode/porocilo_jadran. pdf, accessed January 2013).

ANONYMOUS.2015.KrajinskiparkStrunjan(Strunjan Landscape Park) (http://www.parkstrunjan.si/ index.php?page $=$ static\&item $=62$ ) Accessed November 2015.

ATKINSON, R.J.A. \& C. FROGLIA. 2000. Burrow structures and eco-ethology of burrowing fauna in the Adriatic Sea. In: Giovanardi O (Editor) Impact of fishing on benthic communities: Instituto Centrale per la Ricerca Scientifica e Tecnologica Aplicata al Mare (ICRAM). Rome, 79-94 pp.

ATKINSON, R.J.A. \& A.C. TAYLOR. 2005. Aspects of the physiology, biology and ecology of Thalassinidean shrimps in relation to their burrow environment. Oceanogr. Mar. Biol., 43: 173-210.

CONIDES, A.J., A. NICOLAIDOU, M. APOSTOLOPOU- 
LOU \& M. THESSALOU-LEGAKI. 2012. Growth, mortality and yield of the mudprawn Upogebia pusilla (Petagna, 1792) (Crustacea: Decapoda: Gebiidea) from western Greece. Acta Adriat., 53(1): 87-103.

COSTLOW, J.D. JR \& C.G. BOOKHOUT. 1971. The effect of cyclic temperatures on larval development in the mud crab Rhithropanopeus harrisii. Mar. Biol., 32(3): 215-221.

DE GRAVE, S., N.D. PENTCHEFF, S.T. AHYONG, T.Y. CHAN, K.A. CRANDALL, P.C. DWORSCHAK, D.L. FELDER, R.M. FELDMAN, C.H.J.M. FRANSEN, L.Y.D. GOULDING, R. LEMAITRE, M.E.Y. LOW, J.W.MARTIN, P.K.L. NG, C.E.SCHEWEITZER, S.H. TAN, D. TSHUDY \& R. WETZER. 2009. A classification of living and fossil genera of Decapod crustaceans. Raffles. B. Zool., 21: $1-109$.

DWORSCHAK, P.C. 1981. The pumping rates of the burrowing shrimp Upogebia pusilla (Petgana) (Decapoda, Thalassinidea). I. The burrows. J. Exp. Mar. Biol. Ecol., 52: 25-35. DWORSCHAK, P.C. 1983. The biology of Upogebia pusilla (Petagana) (Decapoda, Thalassinidea). I. The burrows. Pubblicazioni della Stazione Zoologica di Napoli I: Mar. Ecol., 4(1): 19-43.

DWORSCHAK, P.C. 1987a. The Biology of Upogebia pusilla (PETAGNA) (Decapoda, Thalassinidea) II. Environments and Zonation. Mar. Ecol., 8: 337-358.

DWORSCHAK, P.C. 1987b. Feeding behaviour of Upogebia pusilla and Callianassa tyrrhena (Crustacea, Decapoda, Thalassinidea). Investigacion Pesquera, 51(1): 421-429.

DWORSCHAK, P.C. 1988. The Biology of Upogebia pusilla (PETAGNA) (Decapoda, Thalassinidea) III. Growth and Production. Mar. Ecol., 9(1): 51-77.

DWORSCHAK, P.C. 2004. Biology of Mediterranean and Caribbean Thalassinidea (Decapoda). In: Tamaki A (ed) Proceedings of the Symposium on Ecology of large bioturbator in tidal flats and shallow sublittoral sediments - from individual behavior to their role as ecosystem engineers; 2003 Nov 1-2; Nagasaki. Nagasaki University, 15-22 .

DWORSCHAK, P.C., D.L. FELDER \& C.C. TUDGE.
2012. Chapter 69. Infraorders Axiidae de Saint Laurent, 1979 and Gebiidea de Saint Laurent, 1979 (formerly known collectively as Thalassinidea). In: Schram FR, Vaupel Klein von JC, Forest J, Charmantier-Daures M (eds) Treatise on Zoology - Anatomy, Taxonomy, Biology: The Crustacea. Volume 9, Part B. Koninklijke Brill NV Leiden, the Netherlands: 109-220.

FERRARESE, S., C. CASSARDO, A. ELMI, R. GENOVESE, A. LONGHETTO, M. MANFRIN \& R. RICHARDONE. 2009. Air-sea interactions in the Adriatic basin: simulations of Bora and Sirocco wind events. Geofizika, 26: 157 170.

GLASNOVIĆ, P. 2006. Flora slovenskega dela Miljskega polotoka (kvadranta 0448/1 in $0448 / 2$ ) (Flora of the slovenian part of Muggia peninsula (Quadrants 0448/1 and 0448/2)). Thesis, University of Ljubljana, $108 \mathrm{pp}$.

GRBEC, B., I. VILIBIĆ, A. BAJIĆ, M. MOROVIĆ, G. BEC PAKLAR, F. MATIĆ \& V. DADIĆ. 2007. Response of the Adriatic Sea to the atmospheric anomaly in 2003. Ann. Geophys., 25: 835-846.

HAMMER, Ø. 1999-2013. PAST, PAlaeontological STatistics, version 3.0. Reference manual. Natural History Museum, University of Oslo, 221 p. (http://www.nhm2.uio.no/norlex/past/ pastmanual.pdf).

HILL, B.J. 1977. The effect of heated effluent on egg production in the estuarine prawn Upogebia africana (Ortmann). J. Exp. Mar. Biol. Ecol., 29: 291-302.

HORVAT, E. 2013. Ekologija škardoble (Upogebia pusilla) v slovenskem morju. Univerza na Primorskem; Fakulteta za matematiko, naravoslovje in informacijske tehnologije, $57 \mathrm{pp}$.

INGLE, R.W. 1997. Crayfishes, lobsters and crabs of Europe: an illustrated guide to common and traded species. Chapman \& Hall. Cambridge University Press., 281 pp.

JOGAN, N., M. KOTARAC \& A. LEŠNIK. 2004. Opredelitev območij evropsko pomembnih negozdnih habitatnih tipov s pomočjo razširjenosti značilnih rastlinskih vrst: končno poročilo (final report). Center za 
kartografijo favne in flore, Miklavž na Dravskem polju (Slovenia), $961 \mathrm{pp}$.

KAISER M.J., J.A. MARTIN, S. JENNINGS, D.N. THOMAS, K.A., D.K.A. BARNES, A.S. BRIERLEY, J.G. HIDDINK, K. HERMANNI, N.V.C. POLUNIN \& D.G. RAFFAELLI. 2011. Marine Ecology: Processes, Systems and Impacts. Oxford University Press, 528 pp.

KEVREKIDIS, T., N. GOUVIS, A. KOUKOURAS. 1997. Population dynamics, reproduction and growth of Upogebia pusilla (Decapoda, Thalassinidea) in the Evros delta (North Aegean Sea). Crustaceana, 70 (7): 799-812.

LAPRISE R., DODSON, J. J. 1994. Environmental variability as a factor controlling spatial patterns in distribution and species diversity of zooplankton in the St. Lawrence Estuary. Marine ecology progress series, 107: 67-81, LIČER M., M. JEROMEL, M. VODOPIVEC. 2011. Prognozirano plimovanje morja 2011. Jadransko morje - Koprski zaliv (Tide tables 2011. Adriatic Sea - The Gulf of Koper). Ministrstvo za okolje in prostor. Agencija RS za okolje.

LIČER M., M. JEROMEL, M. VODOPIVEC. 2012. Prognozirano plimovanje morja 2012. Jadransko morje - Koprski zaliv (Tide tables 2012. Adriatic Sea - The Gulf of Koper). Ministrstvo za okolje in prostor. Agencija RS za okolje.

LIPEJ, L. \& T. MAKOVEC. 1997. Prezimovanje črnih lisk Fulica atra v Strunjanski laguni (Wintering of the Common Coot Fulica atra in the Strunjan Lagoon). Acrocephalus, XVIII: 80-81.

LOTRIČ, T. \& V. BREČKO GRUBAR. 2010. Profili kopalnih voda in ocenjevanje obremenjenosti vplivnega območja na primeru kopalnega območja Simonov zaliv - Strunjan in kopališča Terme Krka - Talaso Strunjan (Bathing waters profile and assessment of the impact area in San Simon bay and water park Terme Krka - Talaso Strunjan) Thesis, University of Primorska, 190 pp.

MACGINITIE, G.E. \& N. MACGINITIE. 1968. Natural History of Marine Animals. 2nd ed., rev. New York. McGraw-Hill, 523 pp.

MAČEK, M. 2013. Smernice za varovanje habitatnega tipa EU 1320 (sestoji metličja) v Slovenski Istri (Conservation guidelines for habitat type EU 1320 (Spartina swards) in Slovenian Istra). Thesis, University of Primorska, 70 pp.

NGOC-HO N. 2003. European and Mediterranean Thalassinidea (Crustacea, Decapoda). Zoosystema 25(3): 439-555.

PASCAL, L., A.G. DE MONTAUDOUIN \& O. MAIRE. 2016. Dynamics of the marine-host-pasrasite system. Mar. Biol., 163:195. Doi: 10.1007/s00227-016-2969-9

ROBLES, R., C.C. TUDGE, P.C. DWORSCHAK, G.C.B. POORE \& D.L. FELDER. 2009. Molecular phylogeny of the Thalassinidea based on nuclear and mitochondrial genes. In: Martin JW, Crandall KA, Felder DL (eds) Decapod Crustacean Phylogenetics. Crustacean Issues: Taylor and Francis: 309-326.

RODRIGUES, C.V., R.A. COOPER \& S.A. RODRIGUES. 2000. Burrow morphology and behavior of the mud shrimp Upogebia omissa (Decapoda: Thalassinidea: Upogebiidae). Mar. Ecol. Prog., Ser. 200: 229-240.

ŠAJNA, N. \& M. KALIGARIČ. 2005. Vegetation of the Stjuža coastal lagoon in Strunjan landscape park (Slovenia): a draft history, mapping and nature-conservancy evaluation. Ann. Ser. Hist. Nat., 15(1): 79-90.

TODOROVA, V. \& T. KONSULOVA. 2000. Long term changes and recent state of Macrozoobenthic communities along the Bulgarian Black Sea coast. Mediterr. Mar. Sci., 1(1): 123-131. 


\section{Appendices with captions}

Appendix A. Spearman correlation coefficients (below) and p values (above diagonal) for all pairs of environmental parameters and abundance. $* * *-p<0.001 ; * *-0.001<p<0.01 ; *-0.01<p<0.05$; n.s. - nonsignificant

\begin{tabular}{|c|c|c|c|c|c|c|c|c|c|c|c|c|}
\hline & $\begin{array}{l}\text { Tsea } \\
\text { mean }\end{array}$ & Tsed & $\begin{array}{l}\text { Tair__ } \\
\text { mean }\end{array}$ & Tair & $\mathrm{pH}$ & $\mathrm{O}_{2}$ & Sal & Veg & ABU_M & ABU_F & $\begin{array}{r}\mathrm{ABU}_{-} \\
\mathrm{Fov}\end{array}$ & $\mathrm{ABU}_{\text {tot }}$ \\
\hline $\begin{array}{l}\text { Tsea_ } \\
\text { mean }\end{array}$ & & $* * *$ & $* * *$ & $* * *$ & n.s. & $* * *$ & n.s. & $*$ & $* *$ & $*$ & n.s. & $* * *$ \\
\hline Tsed & 0.95 & & $* * *$ & $* * *$ & n.s. & $* * *$ & n.s. & $*$ & * & $*$ & n.s. & * \\
\hline $\begin{array}{l}\text { Tair_ } \\
\text { mean }\end{array}$ & 0.94 & 0.91 & & $* * *$ & n.s. & $* * *$ & n.s. & $*$ & $* *$ & $*$ & n.s. & $* * *$ \\
\hline Tair & 0.91 & 0.98 & 0.88 & & n.s. & $* * *$ & n.s. & $*$ & * & $* *$ & n.s. & * \\
\hline $\mathrm{pH}$ & -0.51 & -0.54 & -0.39 & -0.56 & & n.s. & n.s. & n.s. & n.s. & n.s. & n.s. & n.s. \\
\hline $\mathrm{O}_{2}$ & -0.92 & -0.94 & -0.90 & -0.93 & 0.60 & & n.s. & n.s. & $*$ & $* *$ & n.s. & $*$ \\
\hline Sal & -0.25 & -0.22 & -0.21 & -0.23 & 0.11 & 0.13 & & n.s. & * & n.s. & $* *$ & * \\
\hline Veg & 0.72 & 0.76 & 0.66 & 0.73 & -0.03 & -0.63 & 0.01 & & n.s. & n.s. & n.s. & n.s. \\
\hline ABU_M & 0.77 & 0.76 & 0.81 & 0.72 & -0.45 & -0.66 & -0.64 & 0.41 & & n.s. & $* *$ & $* * *$ \\
\hline ABU_F & 0.72 & 0.77 & 0.75 & 0.77 & -0.24 & -0.81 & -0.30 & 0.63 & 0.62 & & n.s. & $*$ \\
\hline $\begin{array}{l}\mathrm{ABU}_{-} \\
\text {Fov }\end{array}$ & 0.52 & 0.48 & 0.57 & 0.47 & -0.35 & -0.38 & -0.79 & 0.10 & 0.89 & 0.31 & & $* * *$ \\
\hline ABU_tot & 0.82 & 0.78 & 0.83 & 0.77 & -0.36 & -0.72 & -0.66 & 0.47 & 0.93 & 0.77 & 0.81 & \\
\hline
\end{tabular}

Acronyms: Tsea_mean: mean monthly sea temperature $\left[{ }^{\circ} \mathrm{C}\right]$, Tsed : sediment temperature $\left[{ }^{\circ} \mathrm{C}\right]$, Tair_mean : mean monthly air temperature $\left[{ }^{\circ} \mathrm{C}\right]$, Tair: air temperature $\left[{ }^{\circ} \mathrm{C}\right], \mathrm{O}_{2}$ : oxygen $[\mathrm{mg} / \mathrm{ll}$, Sal : salinity [\%o], Veg: vegetation cover $[\%]$, $A B U_{-}$: abundance of males, $A B U_{-} F$ : abundance of non-ovigerous females, $A B U_{-}$Fov: abundance of ovigerous females, $A B U \_$tot: total abundance 
Appendix B. Five millimeters size classes of total body length (TL) in males, non-ovigerous and ovigerous females of Upogebia pusilla in monthly samples from October 2011 until September 2012 from two localities at the Slovenian coast (Lazaret, Strunjan). Largest animal was collected in Lazaret in April 2012 (male, TL = $59.4 \mathrm{~mm}$ : out of scale)
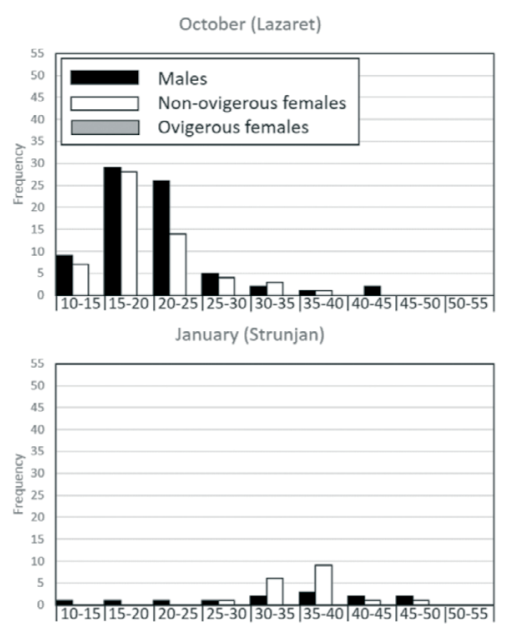

April (Lazaret)

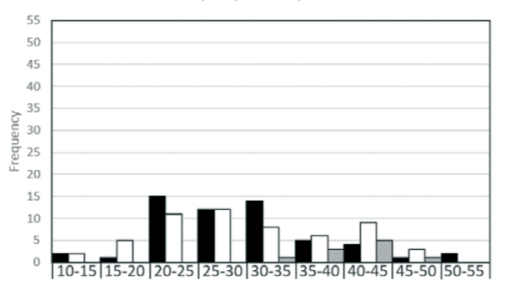

July (Strunjan)

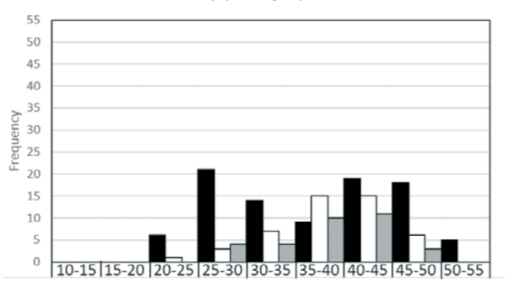

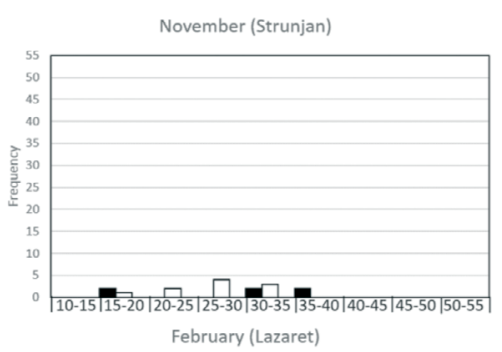

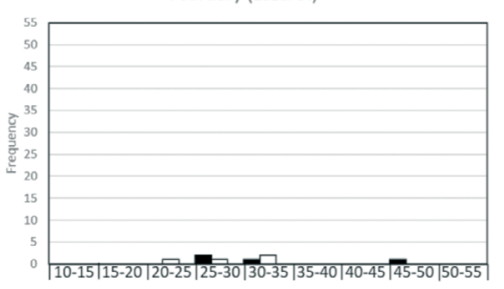

May (Strunjan)

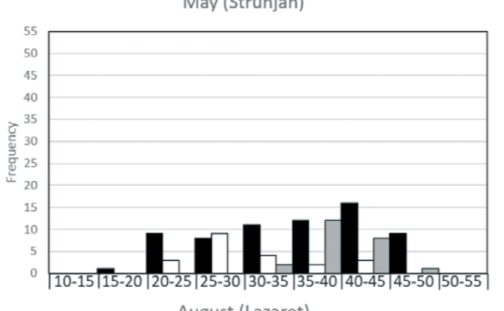

August (Lazaret)

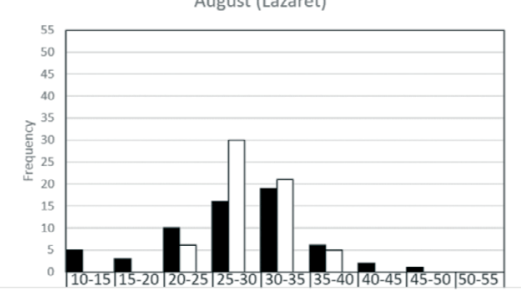

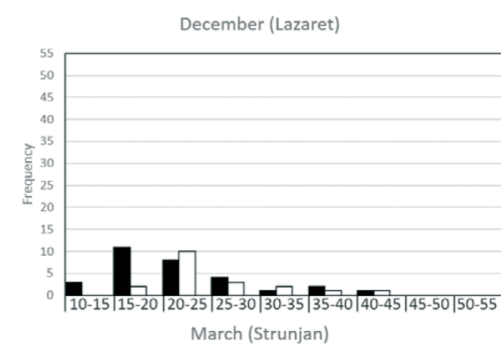

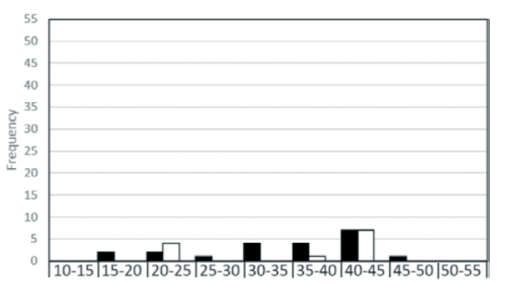

June (Lazaret)

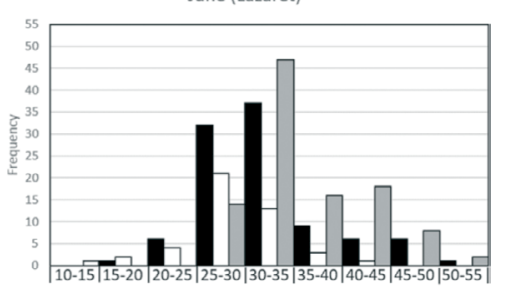

September (Strunjan)

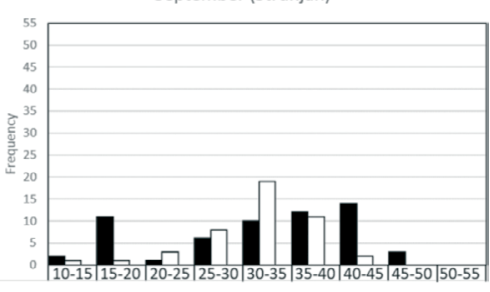




\title{
Sezonska zastupljenost, vertikalna distribucija i ekologija Mediteranskog karlića Upogebia pusilla (Decapoda: Gebiidea) na slovenskoj obali
}

\author{
Jure JUGOVIC*, Eva HORVAT i Lovrenc LIPEJ \\ *Kontakt e-adresa: jure.jugovic@upr.si
}

\begin{abstract}
SAŽETAK
Istraživali smo sezonsku zastupljenost, vertikalnu raspodjelu i povijesne životne osobitosti Mediteranskog karlića (Upogebia pusilla) u Sloveniji. Na dva lokaliteta (Strunjan i Lazaret) izmjenično su uzeti jednom u dva mjeseca kvantitativni uzorci sa tri parcele (svaki $\left.1 \mathrm{~m}^{2}\right)$ na $(0$ $\mathrm{cm})$, ispod $(-50 \mathrm{~cm})$ i iznad $(+50 \mathrm{~cm})$ srednje razine vode. Također je zabilježen skup parametara, uključujući vegetacijsku pokrivenost, vrstu sedimenta, temperaturu zraka i mora, $\mathrm{pH}$, salinitet i razinu kisika. Najveća zastupljenost zabilježena je tijekom toplog razdoblja godine i to u lipnju 2012 godine ( $21 \%$ ukupnog uzorka). Najviša gustoća karlića bila je zabilježena na najnižim parcelama. Mužjaci su prevladavali tijekom zime dok je najveći broj ovigerih ženki zabilježen u lipnju ( $>40 \%$ svih životinja, ili 2/3 svih ženki u lipnju). Procjenjeni srednji inkubacijski period bio je 31 dan. Utvrdili smo četiri razdoblja u vezi sa reproduktivnom aktivnosti ove vrste. Rano razdoblje reprodukcije bilo je obilježeno pojavom prvih ovigerih ženki u travnju, dok je za vrhunac reprodukcije obilježen reproduktivni period travanj-srpanj. U post-reproduktivnom (kolovoz-listopad) i ne-reproduktivnom periodu (studeni-ožujak) nisu bile zabilježene ovigere ženke ili juvenilne životinje.
\end{abstract}

Ključne riječi: abiotski čimbenici, zastupljenost, varijabilnost u prostoru i vremenu 